\title{
Pengaruh penggunaan pembelajaran kooperatif tipe STAD berbantuan program Geometer's Sketchpad terhadap kemampuan berpikir kreatif matematik siswa SMP
}

\author{
Satya Santika \\ Program Studi Pendidikan Matematika, Fakultas Keguruan dan Ilmu Pendidikan, \\ Universitas Siliwangi, Tasikmalaya, Indonesia \\ E-mail: satyasantika@unsil.ac.id
}

\begin{abstract}
This study aimed to determine the increasement of mathematical creative thinking abilities of secondary school student after learning through cooperative learning Student Teams Achievement Divisions (STAD). This study used quasi-experimental design with a control group not equivalent. The study involved an experimental class given STAD cooperative learning assisted Geometer's Sketchpad (GSP) and the control class was only given expository learning. Instruments used a set of mathematical creative thingking tests and questionnaires attitudes. The results showed that the student's mathematical creative thinking ability can be improved through STAD cooperative learning STAD assisted Geometer's Sketchpad.
\end{abstract}

\section{Keywords: Cooperative Learning Model, STAD, Geometer's Sketchpad, Mathematical Creative Thinking}

\section{PENDAHULUAN}

Maraknya penelitiantentangkeberhasilan suatu model, metode,teknik,strategi pembelajaran dalam meningkatkan hasil belajar matematika, bahkan kemampuan matematik siswa, tidak menjamin kesempurnaan pembelajaran matematika SMP di kelas sejauh ini. Tinjauan terhadap beberapa sekolah di Kota Tasikmalaya masih mengarah pada proses pembelajaran matematika di kelas yang bersifat satu arah. Guru masih berperan sebagai satu-satunya sumber pengetahuan sehingga siswa menjadi terbiasa menonton dengan posisi nyaman untuk menerima dan tidak terlatih untuk mencari pengetahuannya sendiri. Pembelajaran seperti ini dimaksudkan sebagai pembelajaran konvensional (Russeffendi, 2006).

Pembelajaran matematika secara konvensional menyebabkan kurang berkembangnya kemampuan siswa dalam bernalar, kurang aktif, bahkan membosankan. Apalagi ditambah fakta bahwa tidak semua siswa menyukai mata pelajaran matematika di sekolah karena berbagai alasan. Hal ini mengindikasikan bahwa perlu adanya perbaikan pembelajaran matematika di sekolah. Karena jika hal ini dibiarkan berlarut, dikhawatirkan berdampak pada rendahnya hasil belajar matematika siswa, walaupun sebenarnya masih banyak faktor lain yang juga turut menentukan.

Alternatif perbaikan kondisi tersebut melalui latihan dalam proses berpikir matematik. Proses berpikir yang dijalani siswa untuk menyelesaikan masalah matematika berkaitan dengan kemampuan mengingat, mengenali hubungan antar konsep, menyadari adanya hubungan antar konsep, menyadari adanya hubungan sebab akibat, analogi atau perbedaan (Ratnaningsih, 2007). Proses ini berimplikasi pada munculnya gagasan siswa yang bersifat orisinal, lancar dan luwes dalam mengambil kesimpulan serat memikirkan kemungkinan penyelesaian lainnya. Kemampuan-kemampuan yang dilatih pada saat siswa menyelesaikan masalah dapat memperkuat daya pikirnya seperti dalam memperoleh, mengelola, dan memanfaatkan informasi dalam upaya bersaing menyongsong masa depannya. 
Proses berpikir tersebut dimuat dalam kegiatan berpikir yang meliputi dua aspekutama yaitu kritis dan kreatif (Suryadi, 2005). Berpikir terjadi di dalam setiap aktivitas mental manusia seperti mengamati, mencerna, mengerti, menjelaskan dan sebagainya yang berfungsi untuk memformulasikan atau menyelesaikan masalah, membuat keputusan, serta mencari pemahaman. Simpson (Munandar, 2002) mengungkapkan pula bahwa kemampuan kreatif merupakan inisiatif yang ditunjukkan seseorang dengan kekuatannya untuk berhenti dari cara berpikir biasa. Hal ini berarti kreativitas dapat memaksa diri sendiri untuk keluar dari cara berpikir yang biasa digunakan sehingga dapat menghasilkan ide-ide baru. Pentingnya kemampuan berpikir dalam pembelajaran matematika dilatihkan kepada siswa sebagai usaha peningkatan kualitas sumber daya. Meskipun setiap siswa memiliki potensi kreatif, tetapi masalahnya bagaimana cara mengembangkan potensi tersebut melalui proses pembelajaran di kelas.

Perkembangan optimal dari kemampuan berpikir kreatif berhubungan erat dengan cara mengajar guru (Munandar, 2004). Kemampuan kreatif dapat tumbuh dalam diri siswa ketiga diberikan kepercayaan oleh gurunya untuk berpikir dalam mengemukakan gagasan baru. Sumarmo (2005) menyarankan bahwa pembelajaran matematika untuk mendorong berpikir kreatif dan berpikir tingkat tinggi dapat dilakukan melalui belajar kelompok kecil, menyajikan tugas non rutin dan tugas yang menuntut strategi kognitif dan metakognitif peserta didik serta menerapkan pendekatan scaffolding. Berpikir kreatif adalah kemandirian, keaslian, kelancaran, kelenturan, elaborasi, dan evaluasi terhadap keterperincian respon siswa dalam menggunakan konsep-konsep, prosedur dan skill dalam matematika. Kemampuan tersebut meliputi kompetensi dapat mengajukan ide-ide baru berdasarkan situasi yang diberikan, melengkapi data dalam menyusun masalah, menggambar atau representasi matematik sesuai dengan karekteristik, menemukan beberapa cara yang mungkin benar, menyusun kemungkinan-kemungkinan penyelesaian suatu masalah, menyusun pola, dan menentukan banyaknya unsur pada pola tertentu serta kesimpulan.

Kegiatan sehari-hari pembelajaran matematika yang terjadi di kelas-kelas di Indonesia pada umumnya belum menghadirkan pembelajaran yang menumbuhsuburkan kemampuan kreatif. Sampai saat ini pembelajaran di sekolah masih menggunakan pendekatan pembelajaran konvensional (Zulkardi, 2001). Pada praktiknya, pembelajaran matematika seakan meminimalisir peluang siswa untuk dapat menggali dan menemukan konsep-konsep matematika secara luas melalui keterlibatanya dalam proses pembelajaran.

Guru matematika pada umumnya mengajar dengan metode ceramah dan ekspositori (Wahyudin, 1999) sehingga kebanyakan siswa hanya dapat memperhatikan setiap penjelasan guru, menerimanya dengan sepenuh hati, dan jarang mengajukan pertanyaan bagi yang tidak terbiasa. Kebanyakan guru tidak menyadari hal ini akan berdampak serius terhadap siswa. Asalkan materi dapat terselesaikan sesuai target kurikulum, proses pembelajaran dianggap selesai. Akibatnya kemandirian siswa dalam memecahkan masalah (problem solving) yang menjadi jantung pembelajaran matematika hampir tidak pernah dilakukan siswa. Pada kondisi seperti ini, kesempatan siswa untuk menemukan dan membangun pengetahuan sendiri hampir tidak ada, mengakibatkan siswa kurang memiliki kemampuan menganalisis dan memecahkan masalah. Oleh karena itu, guru sebaiknya dapat memilih strategi yang tepat sehingga proses pembelajaran dapat menyenangkan bagi siswa dan juga dapat mengaktifkan keterlibatan siswa dalam belajar.

Salah satu alternatif yang dapat menutupi kelemahan uraian pembelajaran di atas adalah dengan menerapkan pembelajaran kooperatif (cooperative learning) yang saat ini banyak digunakan untuk mewujudkan kegiatan belajar mengajar yang berorientasi kepada siswa (student oriented), terutama mengatasi permasalahan yang ditemukan guru dalam 
mengaktifkan siswa yang tidak dapat bekerja sama dengan orang lain, siswa yang agresif dan tidak peduli pada yang lain (Isjoni, 2009). Pembelajaran kooperatif dilaksanakan dalam kelompok kecil, siswa belajar dan bekerja sama dalam menimba pengalaman belajar hingga mencapai tiitk klimaks, baik individu maupun kelompoknya. Manfaat yang dapat diperoleh siswa ketika belajar kooperatif dijelaskan oleh Filsaime (2008) bahwa melalui proses belajar kooperatif, para siswa bisa mendengar perspektif-perspektif yang lain, menganalisis klaimklaim, mengevaluasi bukti-bukti, menjelaskan, dan menjustifikasi penalaran mereka.

Hasil penelitian yang dilakukan oleh Tarim dan Akdeniz (2007) menyimpulkan bahwa pembelajaran kooperatif ditemukan lebih efektif dari metode lain dalam hal meningkatkan prestasi akademik, hubungan yang positif dengan teman dalam kelompok dan saling menguntungkan dan penghargaan terhadap diri sendiri. Pembelajaran kooperatif membuka peluang siswa untuk dapat berbicara, menyikapi sebuah pendapat, serta fokus pada penyelesaian masalah. Selanjutnya hasil penelitian Rogert dan Johnson (Marzuki, 2006) menyimpulkan bahwa tingkat penalaran, munculnya ide-ide baru dan solusi lebih besar pada kelas cooperative learning dibandingkan dengan pembelajaran individual. Bebarapa pendapat tersebut, penerapan model pembelajaran kooperatif yang kondusif dapat memberikan dampak positif bagi pengembangan kemampuan berpikir kreatif matematik siswa.

Bila dibandingkan dengan model pembelajaran kooperatif lainnya, STAD menjadi salah satu pembelajaran kooperatif yang banyak diteliti dan paling direspons oleh siswa. Pada praktiknya, STAD tidak terlalu membebani siswa dengan aturan tertentu sehingga terkesan memiliki tahapan pembelajaran yang paling sederhana jika dibandingkan dengan pembelajaran kooperatif lainnya. Slavin (2009) menjelaskan lima komponen utama pembelajaran kooperatif tipe STAD sebagai berikut: 1) presentasi kelas, 2) kelompok, 3) kuis, 4) skor kemajuan individual, dan 5) rekognisi kelompok. Hasil penelitian Slavin menyebutkan bahwa penggunaan STAD dalam pembelajaran matematika di kelas yang di dalamnya terdapat siswa-siswa yang memiliki hambatan akademis, telah berjalan efektif baik untuk meningkatkan pengetahuan, perilaku, dan meningkatkan penerimaan terhadap mereka oleh teman sekelas mereka. Harapan berikutnya melalui hasil penelitian tersebut, model pembelajaran kooperatif tipe STAD diharapkan mampu menumbuhkan kerja sama tim dalam kelompok, meningkatkan keaktifan siswa, siswa mampu menyampaikan ide-ide/ gagasan yang berhubungan dengan materi yang sedang dipelajari, sehingga dari sini siswa mampu mengembangkan kemampuan berpikir kreatif matematik siswa.

Penelitian ini memanfaatkan komputer sebagai media pembelajaran untuk membantu siswa memperoleh pengetahuan dengan cara lain. Program Geometer's Sketchpad (GSP) sebenarnya merupakan software matematika dinamis yang mempelajari geometri, aljabar, kalkulus, dan materi matemtika lainnya. Penggunaan GSP dalam pembelajaran geometri diharapkan dapat membantu siswa dalam mengonstruksi suatu titik, garis, segmen garis, bangun segi-n, ataupun kurva tertentu yang dapat dimanipulasi. Proses pembuktian konsep geometri dilakukan melalui perhitungan ataupun simulasi sederhana. GSP difasilitasi untuk dapat merekam setiap kegiatan yang telah dilakukan, sehingga sangat mudah jika ingin melakukan pengulangan materi.

The Geometer's Sketchpad dibuat untuk membawa para siswa melalui tingkatan-tingkatan berpikir tersebut. Menurut Carter (2003), The Geometer's Sketchpad memiliki kemampuan dalam hal melakukan tugas utama yaitu: (1) konstruksi Euclid (membuat titik, garis, ruas garis, sinar garis, lingkaran, garis sejajar, garis tegak lurus, titik tengah, busur, dll); (2) transformasi (pencerminan, dilatasi, rotasi dan transformasi, animasi atau objek yang bergerak); (3) analitik Geometri (memplot objek pada koordinat X-Y, koordinat polar r- $\alpha$ 
,persamaan garis dan lingkaran); (4) memadukan Grafik dan Teks (menunjukkan teks, label pada grafik); (5) mengubah properties visual dari objek-objek geometri yang ditampilkan (memanipulasi objek, mempertegas dengan pilihan warna); dan (6) pengukuran (misalnya melakukan pengukuran jarak, panjang, sudut, kemiringan, menghitung luas daerah, keliling lingkaran). Integrasi Geometer's Sketchpad ke dalam lingkungan pembelajaran kooperatif dapat memberikan alternatif baru dalam pembelajaran geometri.

Siswa yang terlibat dalam penggunaan GSP berkesempatan untuk melihat konsep geometri dalam bentuk lain. Bahkan Hoehn (Lam, 2007) mengutarakan bahwa siswa dapat membuktikan teorema-teorema yang ada pada geometri dengan bantuan GSP. Bahkan secara rinci Villiers (1998) mengatakan bahwa dengan GSP siswa mampu mentransformasi gambar secara dinamis, siswa mampu memeriksa serangkaian kasus serupa dan mengarahkan mereka untuk melakukan generalisasi terhadap sifat-sifat segitiga, segiempat, lingkaran, dan konfigurasi geometris lainnya. Oleh karena itu, sebagai aplikasi geometri yang telah mendunia, program GSP dapat dijadikan alternatif terbaik untuk memecahkan masalah termasuk dalam penelitian geometri.

Pembelajaran geometri diberikan kepada siswa tingkat sekolah dasar hingga perguruan tinggi. Akan tetapi hasil penelitian masih menunjukkan bahwa geometri masih sangat lemah untuk diserap oleh siswa di sekolah (Jiang, 2008). Penelitian lain juga menunjukkan bahwa masih minimnya pengetahuan dan/atau pengalaman mengenai sifat-sifat bangun geometri untuk siswa tingkat sekolah menengah. Tidak heran bila pada pembelajaran segitiga, masih ada siswa SMP yang mengira bahwa sisi alas suatu segitiga selalu terletak di bagian bawahnya. Anggapan tersebut tentu salah karena semua sisi pada suatu segitiga dapat dijadikan sebagai sisi alas segitiga.

Uraian di atas memfokuskan penelitian ini pada peningkatan kemampuan berpikir kreatif matematik siswa SMP melalui penggunaan pembelajaran kooperatif STAD berbantuan Program Geometer's Sketchpad.

\section{METODE PENELITIAN}

Penelitian ini termasuk penelitian quasi eksperimen dengan desain kelompok kontrol tidak ekuivalen (the nonequivalent control group design). Subjek tidak dikelompokkan secara acak, tetapi peneliti menerima keadaan subjek seadanya (Ruseffendi, 2005). Desain ini digunakan atas dasar kebijakan institusi tempat penelitian dilaksanakan yang merasa keberatan bila pengelompokan siswa dilakukan secara acak murni. Selanjutnya pada kelompok yang terpilih tersebut diberikan pretes, perlakukan yang berbeda, dan postes. Perlakukan yang diberikan meliputi perlakuan pembelajaran kooperatif tipe STAD berbantuan program GSP dan pembelajaran tanpa diberikan perlakuan khusus pada kelompok kontrol. Instrumen yang diberikan pada saat pretes dan postes berisi tes kemampuan berpikir kreatif matematik. Pada penelitian ini digunakan variabel pengontrol berupa perbedaan kemampuan awal matematika siswa. Hal itu didasarkan pada asumsi bahwa setiap siswa di sekolah manapun memiliki kemampuan awal yang berbeda-beda (unggul dan asor). Variabel ini diduga mempunyai pengaruh yang kuat terhadap kemampuan berpikir kreatif matematik siswa.

Populasi dalam penelitian ini melibatkan seluruh siswa kelas VII SMP 4 Kota Tasikmalaya tahun ajaran 2012/2013. Pemilihan populasi didasarkan pada pertimbangan variasi kemampuan akademik dan tingkatan berpikir siswa. Ada banyak topik matematika kelas VII SMP yang dianggap cocok bila disajikan menggunakan pembelajaran kooperatif tipe STAD berbantuan GSP. Siswa kelas VII SMP merupakan kelas-kelas baru hasil gabungan 
siswa dari beberapa SD dengan gaya belajar yang belum terbentuk sehingga lebih mudah diarahkan dan semangat belajar masih tinggi. Selain itu, peneliti juga berasumsi bahwa siswa pada kelas VII sudah dapat beradaptasi dengan pembelajaran baru. Program sekolah dalam mempersiapkan ujian akhir untuk siswa tingkat akhir pun tidak terganggu dengan pemilihan populasi ini. Penentuan sampel dilakukan secara acak menurut kelas. Sampel terpilih dari kelas VII SMP Negeri 4 Kota Tasikmalaya sebanyak dua kelas.

Soal tes berpikir kreatif matematik bertujuan untuk mengukur kemampuan berpikir kreatif matematik siswa dalam aspek kepekaan, elaborasi, kelancaran, keluwesan, dan keaslian. Tes dilaksanakan sebelum dan setelah proses pembelajaran materi segitiga berlangsung. Tes yang digunakan berbentuk uraian, dengan tujuan untuk melihat proses berpikir, ketelitian dan sistematika penyusunan siswa. Semuanya dapat dilihat melalui langkah-langkah penyelesaian soal dan dapat diketahui kesulitan yang dialami siswa sehingga memungkinkan dilakukan perbaikan. Tahapan penyusunan soal dimulai dari penentuan kisi-kisi soal, penyusunan soal-soal, dan pembuatan kunci jawaban serta pedoman penskoran setiap tiap butir soal. Instrumen tes diujicobakan secara empiris untuk mengetahui reliabilitas seperangkat soal tes, tingkat validitas, daya pembeda, dan tingkat kesukaran butir soal. Pedoman penskoran diadaptasi dari Bosch (1997).

Sebelum dilakukan analisis data, seluruhsiswayangmenjadisubjekpenelitian dikelompokkan ke dalam kategori unggul dan asor. Pengelompokan ini dilakukan berdasarkan hasil tes harian siswa dari materi sebelumnya. Siswa dapat dikelompokkan dalam kategori unggul jika hasil tes hariannya tidak kurang dari rata-rata tes, sementara dalam kondisi lainnya ditempatkan dalam kelompok asor.

Data yang diperoleh melalui tes kemampuan kreatif matematik, kemudian dianalisis dan diberikan tafsiran-tafsiran. Analisis data kuantitatif dilakukan untuk masing-masing pasangan kelompok data sesuai dengan permasalahannya. Analisis terhadap data hasil tes dilakukan untuk mengetahui seberapa besar peningkatan kemampuan berpikir kreatif matematik siswa. Analisa dilakukan dengan cara membandingkan data primer hasil tes siswa sebelum (pretes) dan setelah (postes) perlakuan. Analisis data statistika menggunakan uji ANOVA satu jalur dan dilanjutkan dengan uji pasangan (post-hoc).

\section{HASIL DAN PEMBAHASAN}

Penelitian ini menghasilkan beberapa temuan mengenai kemampuan berpikir kreatif yang dianalisis berdasarkan kelas pembelajaran dan kemampuan awal matematika yang mengelompokan siswa dalam dua kategori, yaitu unggul dan asor. Kemampuan awal matematika adalah kemampuan yang dimiliki siswa sebelum pembelajaran berlangsung. Skor rerata kemampuan awal matematika pada kelas eksperimen sebesar 64,00 dan pada kelas kontrol sebesar 65,55. Skor rerata kemampuan awal matematika pada ketiga pembelajaran perbedaannya tipis sehingga dapat dikatakan relatif sama. Bila dilihat lebih spesifik, skor rerata siswa kelompok unggul, pada kelas eksperimen sebesar 75,95 dan kelas kontrol sebesar 76,39. Sementara skor rerata siswa kelompok asor, pada kelas eksperimen sebesar 58,25 dan pada kelas kontrol sebesar 58,77.

Kemampuan awal matematika siswa pada kelompok unggul dan asor relatif sama. Berdasarkan kesamaan kemampuan awal matematika siswa, sampel dimungkinkan dapat memulai pembelajaran dari awal yang sama dan siswa siap menerima materi pelajaran baru dengan menggunakan pembelajaran yang ditentukan peneliti. 
Hasil penelitian menunjukkan bahwa secara signifikan tidak terdapat perbedaan hasil pretes kemampuan berpikir kreatif matematik siswa pada kelas eksperimen dan kontrol. Meskipun demikian, bila dilihat dari rata-rata pretes, kelas eksperimen ternyata memiliki rata-rata lebih tinggi dibandingkan dengan siswa pada kelas kontrol. Temuan ini didukung perolehan skor rerata pretes kemampuan berpikir kreatif pada kelas eksperimen sebesar 6,25 (22,32\% dari skor ideal yaitu 28); lebih baik daripada kelas kontrol sebesar 5,98 (21,36\%). Pengujian terhadap ketiga rata-rata pretes kemampuan berpikir kreatif menunjukkan tidak terdapat perbedaan yang signifikan. Hal ini dapat berarti bahwa sampel memiliki modal berpikir kreatif matematik yang sama. Dalam hal ini sekurangnya terlihat bahwa siswa telah memiliki modal sekurangnya 20\% kemampuan berpikir kreatif matematik yang berpotensi untuk ditingkatkan.

Analisis data terhadap skor postes menunjukkan adanya perbedaan yang signifikan antara kelas eksperimen dan kelas kontrol. Rata-rata skor postes bagi siswa pada kelas eksperimen juga masih memiliki rata-rata lebih tinggi dibandingkan dengan siswa pada kelas kontrol. Temuan ini didukung perolehan skor rerata postes kemampuan berpikir kreatif pada kelas eksperimen sebesar 22,45 (80,18\% dari skor ideal yaitu 25); yang lebih tinggi daripada kelas kontrol sebesar 14,83 (52,96\%). Pengujian secara statistik terhadap rata-rata postes berpikir kreatif menunjukkan adanya perbedaan yang signifikan. Artinya terdapat perbedaan kemampuan berpikir kreatif matematik siswa setelah diberikan perlakuan berbeda pada masing-masing kelas.

Peningkatan kemampuan berpikir kreatif matematik dilihat dari nilai gain skor pretes ke postes yang diperoleh siswa. Analisis statistika menunjukkan bahwa terdapat perbedaan signifikan mengenai peningkatan kemampuan berpikir kreatif matematik siswa pada kelas eksperimen dan kelas kontrol. Perbedaan ini didukung melalui rata-rata gain pada kelas eksperimen yang cenderung lebih tinggi dari rata-rata gain pada kelas kontrol. Perbedaan kemampuan berpikir kreatif matematik didukung melalui rata-rata gain berpikir kreatif pada kelas eksperimen sebesar 0,7419 (kategori tinggi) dan pada kelas kontrol sebesar 0,3983 (kategori sedang). Rata-rata gain berpikir kreatif tersebut mengindikasikan bahwa pada kelas eksperimen terjadi peningkatan kemampuan berpikir kreatif matematik sebesar $74,19 \%$ yang ternyata lebih tinggi dibandingkan peningkatan yang terjadi pada kelas kontrol sebesar 39,83\%. Berdasarkan skor gain dapat disimpulkan bahwa peningkatan kemampuan berpikir kreatif matematik siswa kelas eksperimen lebih baik daripada kelas kontrol.

Perolehan data dari keseluruhan tes yang dilaksanakan tersebut menggambarkan pembelajaran yang diterapkan cukup berpengaruh terhadap kemampuan berpikir kreatif matematik siswa, meskipun hasilnya belum optimal. Pembelajaran pada kelas eksperimen lebih berpengaruh terhadap kemampuan berpikir kreatif matematik dibandingkan dengan pembelajaran pada kelas kontrol. Hal ini disebabkan pembelajaran kelas eksperimen mengombinasikan pembelajaran kooperatif STAD dengan bantuan GSP sehingga lebih memberikan kesempatan kepada siswa untuk mengenali dan mengevaluasi suatu topik segitiga dengan mengidentifikasi hal-hal yang diperlukan, melengkapi informasi soal, melakukan investigasi, eksplorasi, memecahkan masalah, menggeneralisasi, yang semuanya itu melatih siswa dalam berpikir kreatif matematik.

Temuan lain menunjukkan bahwa peningkatan kemampuan berpikir kreatif pada kelompok unggul pada kelas eksperimen sebesar $86,84 \%$ (gain tinggi) dan pada kelas kontrol sebesar 41,51\% (gain sedang). Begitu pula dengan peningkatan kemampuan berpikir kreatif matematik kelompok asor masih berada pada kualifikasi gain sedang. Peningkatan kemampuan berpikir kreatif matematik siswa kelompok unggul lebih tinggi daripada siswa kelompok asor baik pada kelas eksperimen maupun kelas kontrol. Hal ini menggambarkan 
siswa pada kelompok unggul dapat lebih cepat beradaptasi dibandingkan dengan siswa pada kelompok asor. Berdasarkan skor rerata gain yang diperoleh, baik pada kelompok unggul maupun pada kelompok asor, kemampuan berpikir kreatif matematik pada kelas eksperimen ternyata lebih meningkat jika dibandingkan dengan kelas kontrol. Ini berarti, interaksi kelas pembelajaran dengan kemampuan awal matematika memberikan pengaruh terhadap peningkatan kemampuan berpikir kreatif matematik meskipun hasilnya belum optimal.

Temuan lain menunjukkan bahwa peningkatan kemampuan berpikir kreatif kelompok asor pada kelas eksperimen sebesar 68,10\% bahkan mampu mengungguli kelompok asor pada kelas kontrol yang hanya memperoleh $38,45 \%$. Bahkan yang lebih mengesankan lagi peningkatan kemampuan berpikir kreatif matematik kelompok asor pada kelas eksperimen yang ternyata dapat mengungguli kelompok unggul pada kelas kontrol. Oleh karena itu dapat disimpulkan bahwa baik pada kelompok unggul maupun kelompok asor, kemampuan berpikir kreatif lebih berhasil ditingkatkan pada kelas eksperimen daripada kelas kontrol. Hal ini dimungkinkan karena pada kelas eksperimen lebih dapat memberikan peluang bagi siswa untuk melatih berpikir kreatif dibandingkan dengan kelas kontrol.

Analisis statistika juga menunjukkan bahwa kemampuan berpikir kreatif matematik pada kelas eksperimen lebih meningkat kelas kontrol jida dilihat berdasarkan kemampuan awal matematika siswa. Walaupun hanya sebatas fasilitas tambahan, GSP terbukti dapat menjadi bantuan untuk melatih kemampuan berpikir kreatif siswa dibandingkan dengan pembelajaran matematika secara konvensional.

Penggunaan GSP yang mampu memvisualisasikan bangun segitiga sehingga konsepnya lebih mudah dipahami. Waktu pembelajaran juga dapat diefisiensi sehingga dapat meluangkan lebih banyak kesempatan untuk menyelesaikan latihan soal yang terkait segitiga. Pengalaman ini tentu tidak didapatkan oleh siswa pada kelas kontrol yang hanya mengandalkan keterangan buku dan guru tanpa terlibat langsung interaktivitas penggunaan GSP.

Temuan ini mendukung penelitian-penelitian yang telah dilakukan sebelumnya, misalnya penelitian Almeqdadi (2000) yang melaporkan bahwa terjadi peningkatan yang signifikan antara hasil belajar siswa yang belajar dengan menggunakan GSP dengan siswa yang belajar tanpa menggunakan GSP. Selain itu temuan ini mendukung hasil penelitian yang dilakukan oleh Syamsuhada (2010), yang memberikan kesimpulan bahwa peningkatan kemampuan berpikir kritis matematik siswa yang memperoleh pembelajaran kooperatif berbantuan GSP lebih baik daripada siswa yang memperoleh pembelajaran matematika secara konvensional. Begitu pula hasil penelitian yang dilakukan Hermanto (2011) yang menyatakan bahwa terdapat perbedaan yang signifikan pada kemampuan generalisasi matematis siswa antara yang memperoleh pembelajaran kooperatif berbantuan GSP, pembelajaran kooperatif tanpa bantuan GSP, dan pembelajaran konvensional.

Temuan lainnya mengenai gambaran sikap siswa terhadap mata pelajaran Matematika, terhadap Pembelajaran kooperatif berbantuan program GSP dan terhadap aspek kemampuan berpikir kreatif matematik. Secara umum siswa menyikapi ketiga aspek tersebut secara positif. Sikap siswa terhadap matematika direspons positif oleh $86,88 \%$ siswa. Hal ini berarti kisaran $13,12 \%$ siswa di antaranya menyatakan masih tidak senang dengan matematika. Sementara sikap siswa terhadap kooperatif tipe STAD berbantuan GSP direspons positif oleh $63,75 \%$ siswa. Respons terhadap pembelajaran yang terlihat lebih kecil dari aspek sikap siswa terhadap matematika menunjukkan pembelajaran kooperatif tipe STAD berbantuan GSP bersifat baru bagi siswa sehingga membuka peluang bagi siswa 
untuk setuju ataupun tidak setuju dengan pembelajaran ini. Sementara itu, sikap terhadap soal-soal berpikir kreatif matematik juga direspons positif oleh 58,13\% siswa. Aspek ini terlihat direspons paling sedikit sehingga menunjukkan bahwa siswa belum terbiasa dengan soal-soal yang diberikan karena sangat berbeda dari jenis soal biasanya. Jika dihubungkan dengan kekeliruan, kesalahan dan kekurangan siswa dalam menjawab soal-soal, rendahnya respons yang diberikan siswa terhadap soal-soal yang diberikan menunjukkan bahwa tidak mudah untuk mengubah gaya belajar dan kebiasaan siswa dalam menyelesaikan soal.

Apabila dilihat dari kelompok siswa (unggul, asor) pada masing-masing kelas, siswa pada kelompok unggul terlihat lebih responsif meskipun kurang dapat bekerja sama atau berbagi idea dengan temannya. Untuk siswa kelompok asor, terlihat lebih termotivasi untuk belajar (hasil wawancara) meskipun kurang aktif karena daya tangkapnya tidak secepat kelompok unggul. Namun tidak menutup bukan berarti tidak ada dari kelompok unggul ataupun kelompok asor yang lebih fleksibel, aktif dalam diskusi dan kecepatan daya tangkapnya lebih baik.

Hal yang dirasakan berat oleh guru ketika satu bahan ajar harus diselesaikan dalam satu kali pertemuan sampai tuntas. Menurut guru setempat, jika satu topik dalam pembelajaran biasa dapat diselesaikan dengan cepat karena adanya unsur intervensi guru pada pembelajaran konvensional, maka jauh berbeda situasinya dengan penerapan pembelajaran kooperatif tipe STAD. Dalam menjalani langkah-langkah pembelajaran kooperatif tipe STAD waktu yang relatif lebih lama dari pada pembelajaran biasa. Terlebih lagi jika materi yang disampaikan juga lebih sulit dari biasanya sehingga tidak jarang mengorbankan efisiensi waktu pembelajaran. Terlepas dari semua kekurangan yang terjadi, ternyata pembelajaran kooperatif tipe STAD berbantuan GSP dapat menciptakan atmosfer pembelajaran yang lebih kondusif bagi siswa dalam hal menemukan dan membangun pengetahuannya, siswa lebih aktif bertanya dan menjawab, siswa lebih percaya diri dalam mengeluarkan pendapat.

Secara keseluruhan, implementasi pembelajaran kooperatif tipe STAD dapat menciptakan siswa aktif dalam diskusi kelompok dalam hal: memecahkan masalah, membangun dan menemukan konsep, berbagi idea dengan temannya, mengajukan pertanyaan terbuka, menjawab pertanyaan, dan memberikan saran. Siswa lebih aktif dan kemampuan berpikir kreatif matematik pada kelas eksperimen lebih baik dari pada kelas kontrol.

Berdasarkan hasil observasi yang dilakukan terhadap aktivitas siswa oleh observer dan hasil pengamatan peneliti sendiri (sebagai guru), pada awal-awal pertemuan siswa nampak bingung dengan hadirnya guru baru, apalagi dengan hadirnya 8 laptop sebagai media tambahan pada pembelajaran kooperatif tipe STAD berbantuan GSP. Berdasarkan hasil wawancara, terungkap bahwa kebingungan siswa karena suasana kelas yang berbeda dengan pembelajaran biasanya karena diseting untuk kepentingan penelitian. Hal ini mengindikasikan bahwa suasana pembelajaran konvensional masih melekat kuat pada siswa.

Kebingungan semakin diperkuat dengan adanya pelaksanaan pretes sebelum pelaksanaan pembelajaran untuk mengerjakan soal-soal berpikir kreatif. Selain itu, pada saat diskusi kelompok tampak hanya kelompok tertentu saja yang aktif, demikian pula pada saat diskusi kelas hanya siswa tertentu saja yang dapat aktif pada suasana tanya jawab, kebanyakan siswa masih belum merespon terhadap pendapat temannya.

Pada awal kegiatan belajar, banyak siswa yang tidak menjawab LKS yang diberikan karena masih kesulitan bagaimana untuk mengisi LKS dan mengikuti instruksi yang ada pada LKS itu. Terlihat hanya beberapa siswa yang memiliki kemampuan di atas rata-rata teman 
sekelasnya yang bisa membuat konstruksi sesuai dengan instruksi pada LKS. Sementara siswa lainnya harus melihat terlebih dahulu bagaimana proses konstruksi dilakukan, baru mereka bisa mengikuti, bahkan ada juga yang merasakan terlalu sulit mengikutinya.

Setelah beberapa kali pertemuan, aktivitas siswa semakin meningkat, hal ini dapat dilihat dari siswa antusias mengikuti pembelajaran; karena pendapatnya merasa dihargai siswa lebih berani bertanya; lebih berani mengemukakan pendapat baik dalam diskusi kelompok maupun dalam diskusi kelas; serta tidak takut salah; bahkan pada akhir-akhir pembelajaran tanpa memberikan kesempatan untuk bertanya, banyak siswa sudah ribut bertanya. Siswa kelompok unggul terlihat mendominasi aktivitas di kelas. Sehingga proses pembelajaran berjalan dengan efektif.

Temuan ini sesuai dengan pendapat Slavin (2009) bahwa pembelajaran kooperatif dapat memacu perkembangan berpikir dan kemampuan pemecahan masalah, serta dapat memenuhi kebutuhan sosial dan prestasi akademik siswa jauh lebih meningkat bila dibandingkan dengan pembelajaran konvensional. Di samping itu Malone dan Krismanto (1997) merekomendasikan penggunaan kegiatan kelompok dalam belajar matematika untuk mendorong motivasi siswa. Mereka juga mengatakan terdapat fakta bahwa siswa mempunyai perkembangan sifat positif dan persepsi yang baik tentang belajar matematika dengan pengelompokan.

Hasil temuan lain berupa kendala yang dihadapi ketika pembelajaran kooperatif tipe STAD berbantuan GSP diterapkan. Kendala pertama, siswa cenderung tidak menghargai waktu bila guru tidak mengontrol kegiatan belajar mereka. Apalagi bila ada yang tidak dipahami pada LKS yang diberikan ataupun penggunaan program GSP. Sebagai antisipasi peneliti mengundang beberapa rekan yang dapat membantu mengarahkan apabila hal tersebut terjadi. Selain itu, siswa diminta untuk mengumpulkan hasil pengerjaan LKS dan penyelesaian soal-soal latihannya.

Kendala kedua fokus pada manajemen waktu pembelajaran. Pada penelitian ini, di dalam kegiatan pembelajaran dilakukan diskusi untuk menjawab LKS berbantuan GSP. Tujuannya untuk memberikan pengalaman kepada siswa, sehingga siswa mendapatkan informasi yang lebih banyak, dan dengan tetap berkesempatan untuk bisa sharing dengan siswa lain. Interaksi antar siswa juga guru-siswa dapat terjadi pada saat kegiatan menyimak LKS berlangsung. Interaksi yang tidak perlu harus dibatasi oleh guru mengingat waktu pembelajaran yang terbatas. Dengan demikian, guru dituntut untuk dapat mengelola waktu agar kegiatan pembelajaran menjadi efisien.

Kendala ketiga ditinjau dari pembelajaran kooperatif tipe STAD berbantuan GSP yang kondusif. Bagi sekolah yang memiliki laboratorium komputer dapat diberdayakan untuk kegiatan pembelajaran, tentu penggunaannya haruslah diatur sedemikian rupa sehingga guru hanya tinggal membawa siswa untuk belajar di laboratorium komputer. Pada penelitian ini tidak digunakan laboratorium komputer sebagai kelas eksperimen dikarenakan setting tempat yang tidak sesuai dengan kepentingan penelitian. Peneliti mendatangkan peralatan yang mendukung pembelajaran ke dalam kelas seperti biasa dan melakukan beberapa pengaturan supaya eksperimen dapat dilaksanakan. Pengaturan tersebut menjamin siswa dan guru merasa nyaman dengan keadaan ruangan, sehingga pembelajaran tidak terhambat karena faktor pengaturan ruangan yang tidak mendukung.

Hasil observasi terhadap siswa yang memperoleh pembelajaran kooperatif tipe STAD berbantuan GSP, ditemukan bahwa sikap siswa menjadi lebih aktif, kreatif dan memiliki semangat yang tinggi dalam belajar. Sejalan dengan hal ini Ruseffendi (2006:283) 
mengemukakan belajar aktif dapat menumbuhkan sikap kreatifnya dikemudian hari lebih berhasil. Maksudnya ialah lebih dapat mengatasi persoalan di masyarakat. Aktivitas siswa dalam memahami materi dilakukan dengan diskusi sesama teman kelompok dan bertanya kepada guru.

\section{SIMPULAN DAN SARAN}

Berdasarkan hasil analisis dan pembahasan temuan penelitian yang telah dikemukakan, peneliti menyimpulkan bahwa kemampuan berpikir kreatif matematik siswa dapat ditingkatkan melalui penggunaan pembelajaran kooperatif tipe STAD berbantuan Geometer's Sketchpad dengan indikator keberhasilannya sebagai berikut: (1) Kemampuan berpikir kreatif matematik siswa yang memperoleh pembelajaran kooperatif tipe STAD berbantuan GSP lebih meningkat jika dibandingkan dengan siswa yang memperoleh pembelajaran konvensional; (2) Peningkatan kemampuan berpikir kreatif matematik siswa yang memperoleh pembelajaran kooperatif tipe STAD berbantuan GSP (asor) lebih baik dari pada siswa yang memperoleh pembelajaran konvensional (unggul, asor). Hal ini menunjukkan bahwa penerapan pembelajaran kooperatif tipe STAD berbantuan GSP berpengaruh secara signifikan terhadap peningkatan kemampuan berpikir kreatif matematik siswa dibandingkan dengan pembelajaran konvensional; (3) Respon siswa terhadap pembelajaran matematika melalui model pembelajaran kooperatif tipe STAD berbantuan GSP positif.

Peneliti menyarankan perlunya dikembangkan pembelajaran kooperatif tipe STAD berbantuan GSP pada jenjang SMP. Khususnya pada materi segitiga. Selain dapat menciptakan suasana pembelajaran lebih kondusif, pembelajaran ini juga memberikan kesempatan pada siswa untuk melakukan manipulasi bangun-bangun geometri melalui lain menggunakan GSP. Dalam pengimplementasiannya, selain mempersiapkan semua komponen pendukung, guju juga diharapkan dapat mengantisipasi berbagai kemungkinan, termasuk mempertimbangkan kemampuan siswa. Bagi kelas dengan rata-rata kemampuan siswa tergolong unggul, lebih tepat diterapkan pembelajaran kooperatif tipe STAD berbantuan GSP. Selain itu faktor kemampuan siswa dalam menggunakan komputer perlu dipertimbangkan pula. Guru matematika dapat mencoba mengombinasikan model pembelajaran lain dengan penggunaan program GSP pada materi segitiga di SMP yang tentunya disesuaikan dengan kebutuhan siswa.

Temuan terhadap pembelajaran kooperatif tipe STAD berbantuan GSP pada materi segitiga menunjukkan secara signifikan yang dapat meningkatkan kemampuan berpikir kreatif matematik siswa SMP diharapkan menjadi bahan masukan bagi sekolah untuk dapat turut memfasilitasi strategi pembelajaran ini agar hasil yang diperoleh maksimal. Implementasi pembelajaran kooperatif tipe STAD pada materi segitiga memerlukan waktu yang relatif lebih lama dibandingkan pembelajaran konvensional, sehingga dalam pelaksanaannya perlu diperhatikan pula efisiensi waktu. Selain itu, diperlukan perhatian lebih bagi siswa kelompok asor agar penggunaan waktu lebih efisien.

Bagi peneliti selanjutnya yang akan menerapkan pembelajaran kooperatif tipe STAD berbantuan GSP pada materi segitiga di SMP dan melihat kemampuan yang sama dengan penelitian ini, perlu menggali lebih jauh dalam membandingkan setiap aspek kemampuan berpikir kreatif (kepekaan, kelancaran, keluwesan, keterperincian, keaslian) bila ditinjau dari keseluruhan aspek dan kemampuan awal matematika siswa. Pada dasarnya masih dibutuhkan penelitian lanjutan, khususnya penelitian pada penerapan pembelajaran kooperatif tipe STAD berbantuan GSP pada materi segitiga terhadap peningkatan 
kemampuan daya matematik lainnya (penalaran, komunikasi, koneksi, pemecahan masalah, dan representasi).

\section{DAFTAR RUJUKAN}

Almeqdadi, F. (2000). The Effect of Using The Geometer's Sketchpad (GSP) on Jordanian Students' Understanding Some Geometrical Concept. [Online]. Tersedia: http://www. cimt.plymouth.ac.uk/journal/almeqdadi .pdf. [19 Januari 2011].

Bosch, N. (1997). Rubric for Creative Thinking Skills Evaluation. [Online]. Tersedia: www. adifferentplace.org/creativethinking.htm [6 Desember 2012]

Carter. (2003). Dynamic Geometry Software. Instructional Technology Coordinator Manteno CUSD \#5 [online] tersedia: http://mathforum.org/dynamic/sketchpadweblinks.html [12 November 2012]

Filsaime, D. K. (2008). Menguak Rahasia Berfikir Kritis dan Kreatif. Jakarta: Prestasi Pustaka.

Hermanto, Redi. (2011). Pengaruh Pembelajaran Kooperatif Tipe STAD Berbantuan Program Geometer's Sketchpad terhadap Kemampuan Generalisasi Matematik Siswa SMP. Tesis pada PPS UPI: tidak diterbitkan.

Isjoni. (2010). Cooperative Learning Efektifitas Pembelajaran Kelompok. Bandung: Alfabeta.

Jiang, Z. (2008), Explorations and Reasoning in the Dynamic Geometry Environment. [Online]. Tersedia: http://atcm.mathandtech.org/EP2008/papers_full/2412008_15336.pdf [10 Nopember 2012]

Lam, T. T. (2007). Use of Geometer's Sketchpad (GSP) to Teach Mechanics Concepts in A Level Mathematics. [Online]. Tersedia: http://epatcm.any2any.us/10thAnniversaryCD/ EP/2004/2004C141/fullpaper.pdf [4 Desember 2012]

Marzuki, A. (2006). Implementasi Pembelajaran Kooperatif (Cooperative Learning) Dalam Upaya Meningkatkan Kemampuan Koneksi Dan Pemecahan Masalah Matematik Siswa (Eksperimen pada MAN Buntet Pesantren Kabupaten Cirebon). Tesis PPS UPI Bandung: Tidak diterbitkan.

Munandar, S. C. U. (2002). Kreativitas dan Keberbakatan Strategi Mewujudkan Potensi Kreatif dan Bakat. Jakarta: Granada Pustaka Utama.

Munandar. (2004). Pengembangan Kreativitas Anak Berbakat. Jakarta: Rineka Cipta.

Ratnaningsih, N. (2007). Pengaruh Pembelajaran Kontekstual terhadap Kemampuan Berpikir Kritis dan Kreatif Matematik Siswa Sekolah Menengah Atas. Disertasi pada Sekolah Pasca Sarjana UPI. Bandung: Tidak diterbitkan.

Ruseffendi, E.T. (2005). Dasar-dasar Penelitian Pendidikan dan Bidang Non-Eksakta Lainnya. Semarang: UNNES Press.

Ruseffendi, E.T. (2006). Pengantar kepada Membantu Guru Mengembangkan Kompetensinya dalam Pengajaran Matematika untuk Meningkatkan CBSA. Bandung: Tarsito.

Slavin, R. E. (2009). Cooperative Learning: Teori, Riset dan Praktik. Bandung: Nusa Media.

Sumarmo, U. (2005). Alternatif Pembelajaran Matematika dalam Menerapkan Kurikulum Berbasis Kompetensi. Makalah pada Seminar Tingkat Nasional FPMIPA UPI: Tidak Diterbitkan.

Suryadi, D. (2005). Penggunaan Pendekatan Pembelajaran Tidak Langsung serta Pendekatan Gabungan Langsung dan Tidak Langsung dalam Rangka Meningkatkan Kemampuan berpikir Matematika Tingkat Tinggi Siswa SLTP. Disertasi pada PPS UPI Bandung: tidak diterbitkan.

Syamsuduha, D. (2010). Pengaruh Pembelajaran Kooperatif Berbantuan Program Geometer's Sketchpad terhadap Kemampuan Berfikir Kritis matematik Siswa SMP. Tesis UPI Bandung: Tidak diterbitkan. 
Tarim, K., Akdeniz, F. (2007). The effects of cooperative learning on Turkish elementary students' mathematics achievement and attitude towards mathematics using TAI and STAD methods. Journal Educ Stud Math (2008) 67: 77-91

Villiers, M. D. (1998). A Sketchpad Discovery Involving Triangles and Quadrilaterals. [Online]. Tersedia: http://mzone.mweb.co.za/residents/profmd/areas.pdf [20 November2012].

Wahyudin (1999). Kemampuan Guru Matematika, Calon Guru Matematika, dan Siswa dalam Mata Pelajaran Matematika. Disertasi pada PPS UPI: tidak diterbitkan.

Zulkardi. (2001). Realistic Mathematics Education (RME). Teori, Contoh Pembelajaran dan Teman Belajar di Internet. Makalah yang disampaikan pada Seminar Nasional pada tanggal 4 April 2001 di UPI: Tidak diterbitkan. 